\title{
NECTARY STRUCTURE AND NECTAR SECRETION OF ECHIUM RUSSICUM J. F. GMEL. FLOWERS
}

\author{
Mirosława Chwil, Elżbieta Weryszko-Chmielewska
}

\author{
Department of Botany, Agricultural University, ul. Akademicka 15, 20950 Lublin, Poland \\ e mail: miroslawa.chwil@ar.lublin.pl
}

Received: 24.04 .2007

\section{S u m m a r y}

In this study, the micromorphology of nectaries in Echium russicum J. F. Gmel. flowers was determined by using scanning electron microscopy (SEM) and their anatomy by using light microscopy (LM). The rate of nectar production of flowers and sugar concentration in nectar were investigated. The nectary gland is located below the ovary of the pistil. It is composed of 4 parts corresponding to the parts of the ovary. The widest regions of the nectar producing tissue are situated by the furrows separating the adjacent parts of the ovary. Nectar is secreted through anomocytic stomata, located only in the lower part of the nectary. The stomata were distributed evenly or they formed clusters of 23 . The average number of stomata on the surface of the whole nectary was 184 . At the nectar secretion stage, open and closed, as well as not fully mature stomata were observed. The orientation of most of the stomata was parallel to the nectary base. The cuticle surface of the cells of the upper and lateral part of the nectary was smooth, whereas in the region produ cing stomata it showed various folds facilitating the retention of nectar. The flowers produced nectar throughout the flowering period. The weight of nectar secreted throughout the lifetime of ten flowers was, on the average, $20 \mathrm{mg}$, with the concentration of sugars of $58 \%$ and their weight reaching $17 \mathrm{mg}$.

Key words: nectary, nectar secretion, epidermis, SEM, Echium russicum, Boraginaceae

\section{INTRODUCTION}

The genus Echium russicum J. F. Gmel. syn. E. rubrum Jacq. is a biennial plant. In Poland's climatic conditions, plants of this taxon bloom from May until August. Tubular flowers with a zygomorphic, intensively red corolla are gathered in cymose inflorescences - drepania (Rutkowski, 2006).

Echium russicum belongs to medicinal plants. It was formerly used as a remedy against viper bites (Rejewski, 1996). This species is also classified as a poisonous plant (S a dow ska, 2004).
Echium russicum is also an ornamental plant, particularly recommended for planting on dry slopes due to its resistance to drought.

Species from the genus Echium have a great apicultural value (S tace, 1992; Valid o et al. 2002). In Australia about $25 \%$ of honeys come from the nectar of Echium (Culvenor, 1985). With the numerous occurrence of Echium vulgare in the natural environment, there is a problem of contamination of honeys with toxic pyrrolizidine alkaloids (heliosupine, lycopsamine and consolidine) originating from this plant $(\mathrm{Culvenor}$, 1985; Beales et al. 2004; Betteridge et al. 2005; Boppre et al. 2005).

The most frequently determined rate of nectar production relates to Echium vulgare found across Europe (Maurizio and Grafl, 1969; Klinkhamer et al. 2001; Leiss et al. 2004). In many papers, attention is drawn to the share of nectar and pollen of $E$. plantagineum in honeys coming from southern Europe (Aira et al. 1998; Terrab et al. 2004; Maia et al. 2005). Few species from the family Boraginaceae are known in terms of the structure of the nectary. The structure of the nectary gland of Symphytum officinale L. (Stpiczyńska, 2003) and Myosotis sylvatica Hoffm. (Weryszko-Chmielewska, 2003) has been described.

The aim of this study was to determine the structure of nectaries and the rate of nectar production of flowers of Echium russicum which is found in Poland only in Lublin Upland (Wyżna Lubelska).

\section{MATERIAL AND METHODS}

The plant material of Echium russicum J. F. Gmel. syn. E. rubrum Jacq. came from the Botanical Garden of the Maria Curie-Skłodowska University in Lublin. The melliferous value of flowers was determined based on 
the calculation of sugar yield by the method described in Jabłoński and Szklanowska (1979). The study was conducted in June 2006.

Nectar was collected using a glass micropipette at $9^{00}$ from isolated flowers, in five samples for three days. Each sample comprised the nectar secreted throughout the lifetime of 15 flowers. In total, the nectar from 75 flowers was analysed. The weight of nectar was weighed and the sugar concentration in the nectar was determined by using a refractometer, as well as the weight of sugars secreted by 10 flowers was calculated.

\section{Scanning electron microscopy (SEM)}

The micromorphology of the nectaries was examined using scanning electron microscopy (SEM). Flower portions, after fixing them in glutaraldehyde, were dehydrated in acetone and dried at critical point with $\mathrm{CO}_{2}$. Then, the sampled plant material was coated with gold and observed in the TESLA BS-300 microscope. The number of stomata was determined on the surface of the nectaries from 5 flowers.

\section{Light microscopy (LM)}

Anatomical observations of the nectaries were made based on semi-thin longitudinal sections with the thickness of pieces of $1 \mu \mathrm{m}$. The sections were prepared in accordance with the method described by Weryszko-Chmielewska (2003).

\section{RESULTS}

In 2006 the flowering of Echium russicum started in the first decade of June. The observed flowers (Fig. 1) lived 2-3 days, on the average.

\section{Micromorphology of nectary}

The nectary gland of E. russicum is located below the ovary. It is composed of 4 parts corresponding to particular fragments of the ovary, surrounding them at the base in the form of a fleshy disk, protruding beyond the ovary, what is clearly visible when the ovary is observed from above (Figs. 2, 3). The width of the protruding portion of the nectary, measured along its radius, is uneven around the periphery of the ovary, and its average dimension is $70 \mu \mathrm{m}$. The widest regions of the nectar-producing tissue are located by the furrows separating the adjacent parts of the ovary (Figs. 2-4). The height of the nectary is $234 \mu \mathrm{m}$, on the average, and it is $1 / 3$ of the height of the ovary (Fig. 3). The outer diameter of the nectary, measured together with the ovary, reaches $1080 \mu \mathrm{m}$. The number of the epidermal cells, calculated from the lower to the upper part of the nectary, was 28-32.

\section{Epidermis structure}

Observed by scanning electron microscopy, the epidermal cells of the nectary were 4-6-angled in their contour. Their outer wall was convex (Figs. 5-7). The dimensions of these cells were 14-27 $\mu \mathrm{m}$. In their size and shape, they were similar to the epidermal cells covering the ovary.

Nectar was secreted through the stomata which occurred only in the lower part of the ovary (Fig. 5). At some places, they were distributed evenly (Fig. 6), at other places they formed clusters 2-3 (Figs. 11, 12). The epidermal cells occurring between them oftentimes had strongly folded walls (Fig. 8), which created the possibility of retaining nectar on their surface.

The stomata occurred at the level of the other epidermal cells. Due to the number of the surrounding cells (6-8), they were classified as the anomocytic type (Figs. $8,10)$. The stomata differed in size. Most frequently, they were circular or slightly elongated. Their dimensions reached $15-20 \mu \mathrm{m}$, on the average $18.40 \mu \mathrm{m}$. The number of stomata on the surface of the whole nectary ranged 156-216 $(n=5)$, with the average value being 184 .

At the nectar secretion stage, both open and closed stomata were observed. Among them, there were also few not fully mature stomata, with a pore covered by the cuticle (Fig. 9). In the mature stomata, well developed outer cuticular ledges were observed, accompanying the stoma (Figs. 10-12). The orientation of most of the stomata was parallel to the nectary base (Fig. 6). The cuticle surface of the cells of the upper and lateral part of the nectary was smooth (Figs. 6,7). But in the region producing stomata, it showed various folds. Circular striae occurred on the outer wall of the guard cells (Figs. $10,12)$, whereas the surface of the subsidiary cells was characterised by the different direction arrangement of striae, sometimes concentrated radially around the stoma (Figs. 9, 10, 12).

\section{Anatomy of the nectary}

The observations of the longitudinal section of the ovary with the nectary show that the nectary gland forms a structure independent of the ovary, surrounding its base separated by its own epidermis (Figs. 13, 14). The tissues of the corolla tube formed a convexity over the nectary protecting the nectary (Fig. 14). The size of the cells of the epidermis and of the glandular tissue of the nectary was similar to the dimensions of the cells forming the ovary wall (Figs. 14, 15). The cells of both the nectary epidermis and the nectar-producing tissue were characterised by thin cell walls (Fig. 16). During nectar secretion, the epidermal cells showed a larger degree of vacuolisation than the cells of the glandular tissue, in particular those located in the deeper layers of the nectary. The branches of the vascular bundles running to the ovary penetrated the central part of the nectary gland (Fig. 17). A number of tracheal elements were visible in this region.

The stomata occurred only in the basal part of the nectary (Figs. 15, 16, 18, 19, 22). They were located at the level of other cells of the epidermis (Fig. 19), in small hollows (Fig. 16), or they were slightly raised 

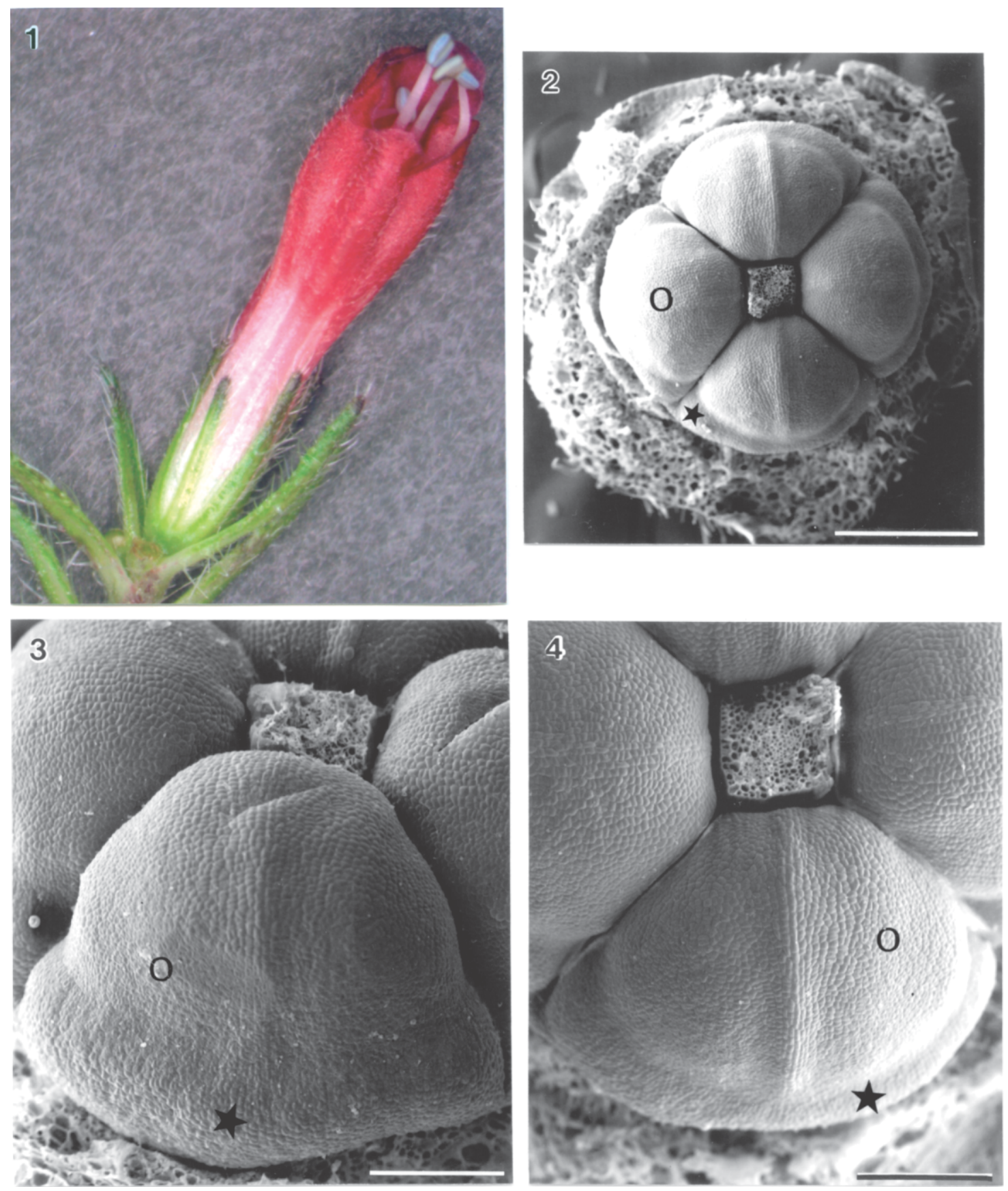

Fig. 1. Echium russicum flower on the first day of flowering.

Fig. 2. Four parted ovary (O) of Echium russicum with the nectary (asterisk) at the base. Bar $500 \mu \mathrm{m}$.

Figs. 3, 4. Fragments of the ovary $(\mathrm{O})$ with visible segments of the nectary (asterisks) at the base of one of the ovary part. Bars $200 \mu \mathrm{m}$. 

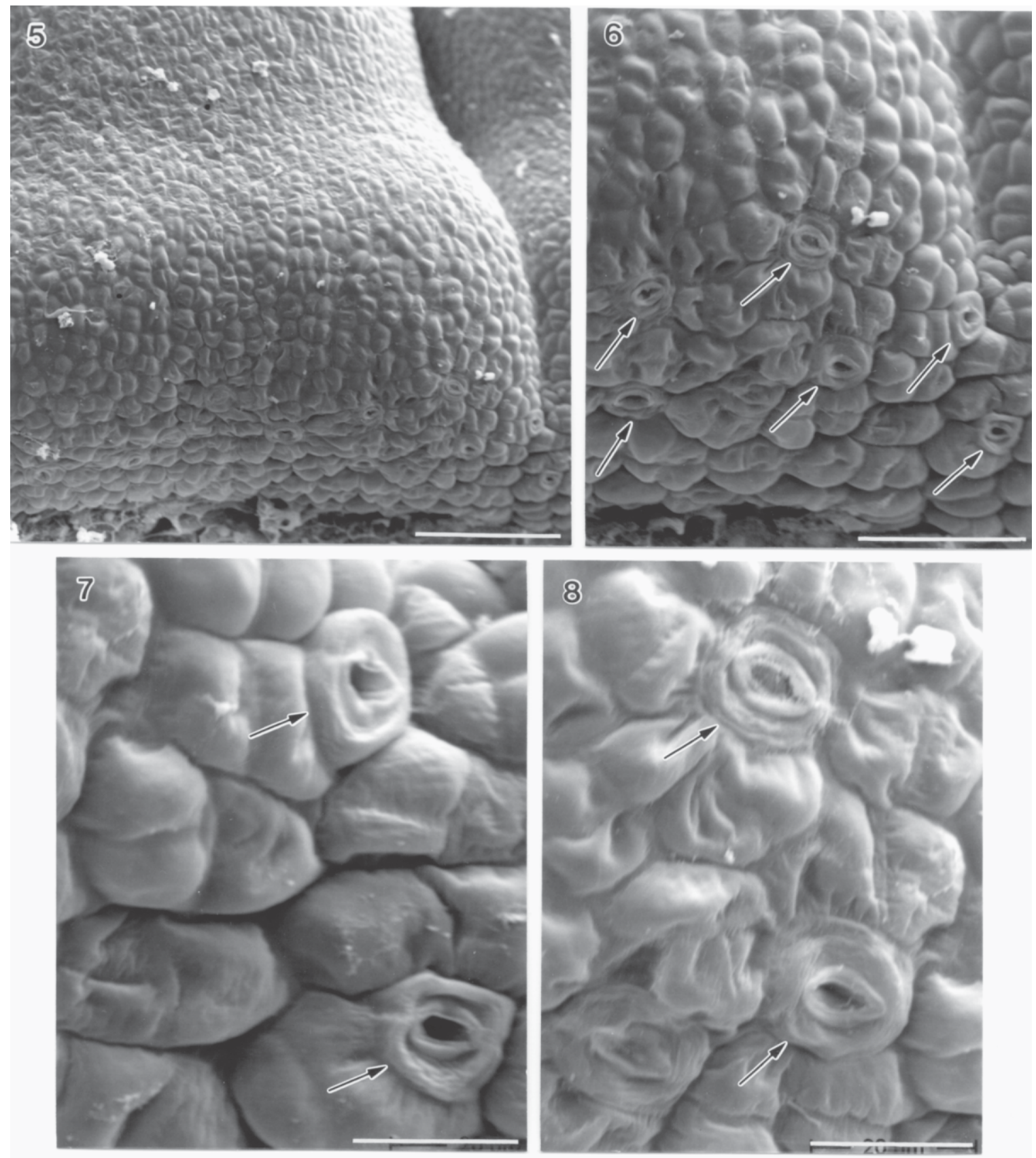

Fig. 5. Fragment of the nectary gland forming a convexity in the vicinity of the basal part of the ovary. Bar $90 \mu \mathrm{m}$. Fig. 6. Fragment of the nectary surface with visible stomata (arrows). Bar $50 \mu \mathrm{m}$.

Figs. 7, 8. Surface of the nectary epidermis with stomata (arrows). Visible folds of cell walls. Bars $20 \mu \mathrm{m}$. 

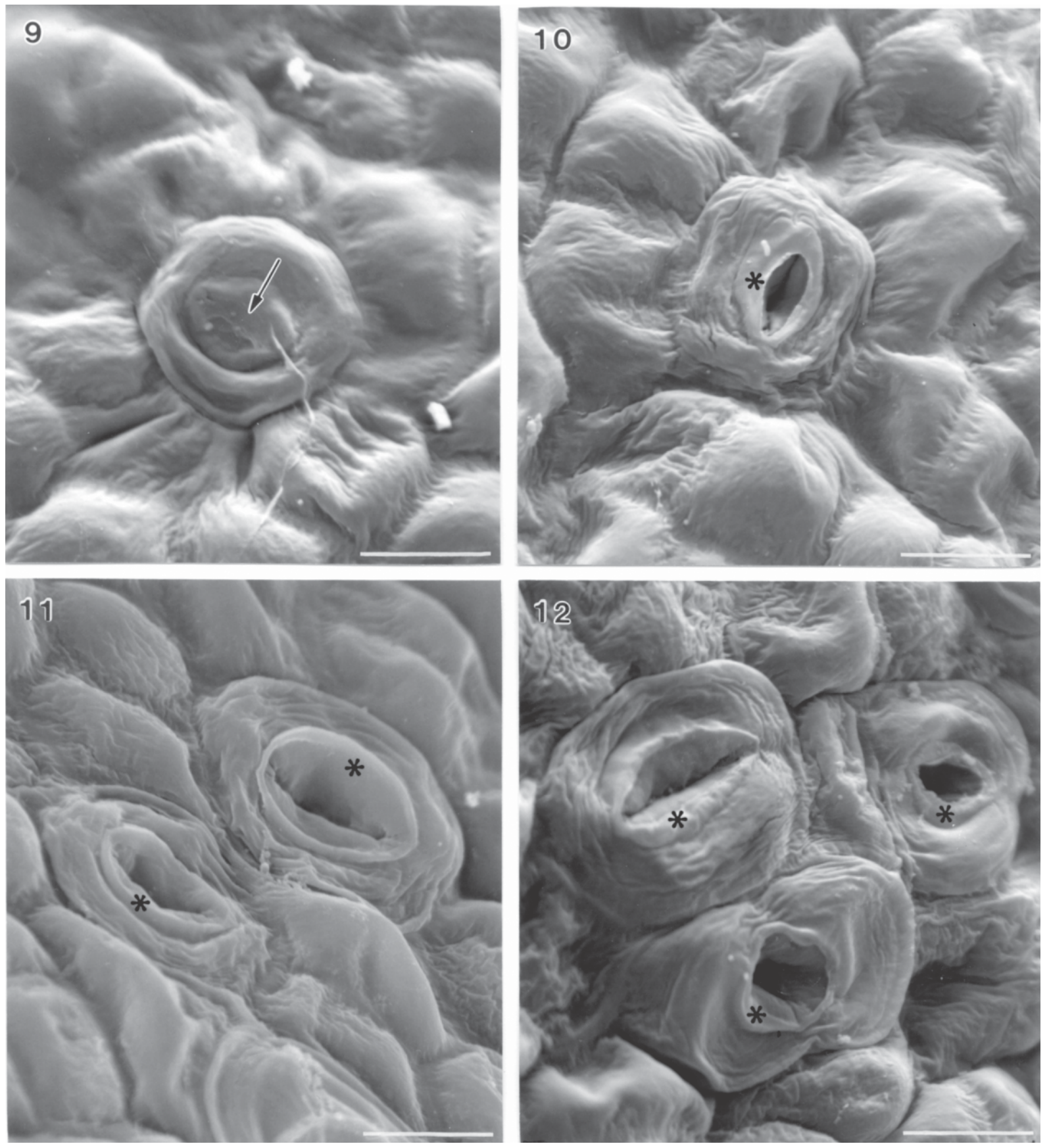

Fig. 9. Stoma from the nectary surface with a pore closed by the cuticle layer (arrows). Bar $10 \mu \mathrm{m}$.

Figs. 10 12. Stomata in the nectary epidermis with well developed outer cuticular ledges (asterisks). Bar $50 \mu \mathrm{m}$. 

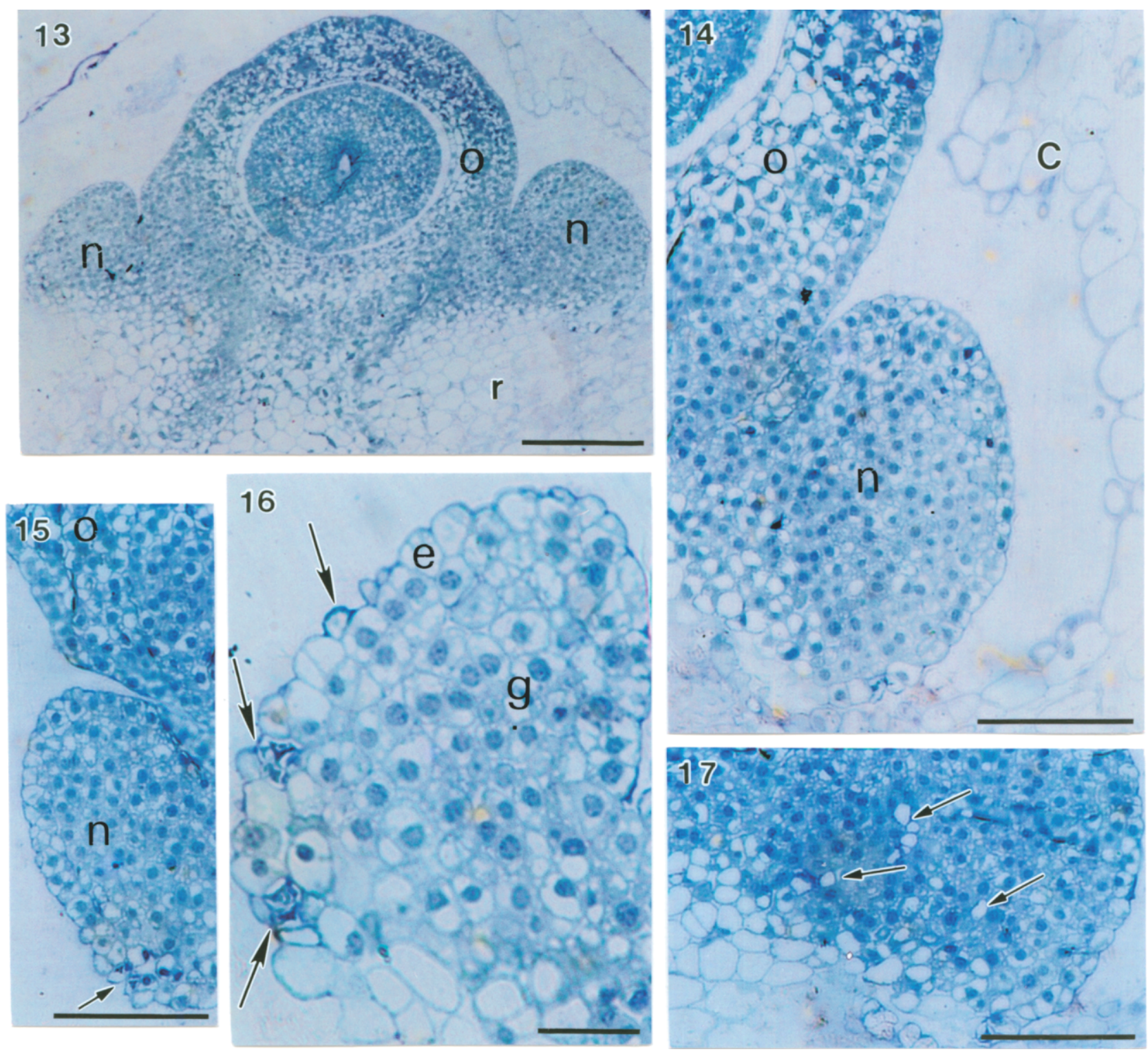

Fig.13. Longitudinal section of the ovary (O) with the nectary (n) and receptacle (r). Bar $\quad 50 \mu \mathrm{m}$.

Fig. 14. Fragment of the ovary (O), nectary (n) and a convex of the tissues of the corolla tube (c) protecting the nectary from the flower longitudinal section. Bar $100 \mu \mathrm{m}$.

Fig. 15. Fragment of the longitudinal section of the nectary with a visible stoma (arrow). Bar $100 \mu \mathrm{m}$.

Fig. 16. Several stomata (arrows) on the outer wall of the nectary; e epidermis, g glandular tissue. Bar $50 \mu \mathrm{m}$.

Fig. 17. Fragment of the nectary with visible tracheal elements (arrows) of vascular bundles. Bar $100 \mu \mathrm{m}$. 

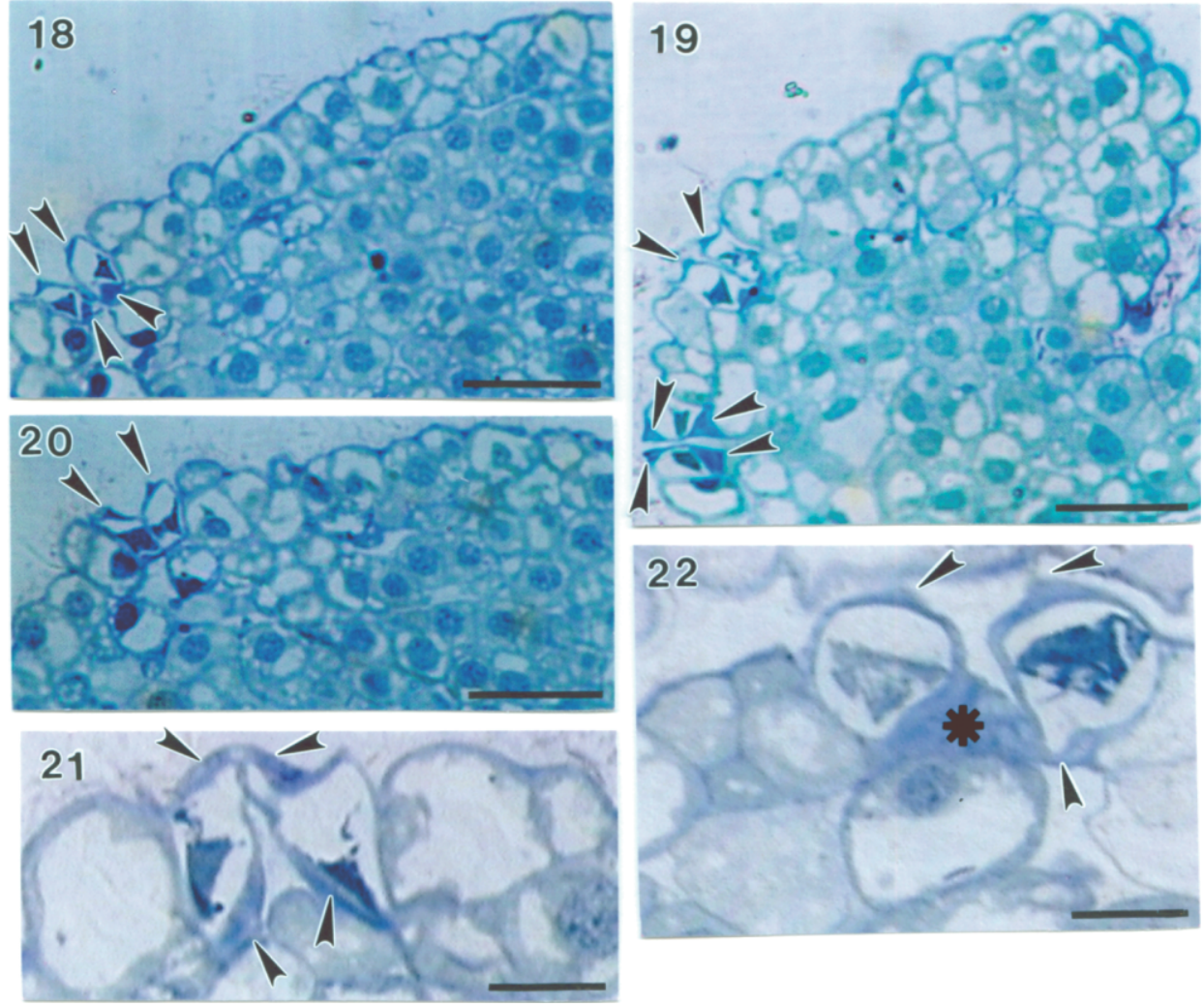

Figs. 18 22. Fragments of longitudinal section of nectaries with visible stomata. Outer and inner cuticular ledges are marked with arrow heads, and nectar deposited beneath the stoma is marked with an asterisk.

Figs. 18, 19, 20 bars $100 \mu \mathrm{m}$, Figs. 21,22 bars $20 \mu \mathrm{m}$.

Table 1

Rate of nectar production of Echium russicum flowers.

\begin{tabular}{|c|c|c|}
\hline \multicolumn{3}{|c|}{ Trait studied } \\
\hline \multirow{5}{*}{$\begin{array}{l}\text { Weight of nectar from } 10 \\
\text { flowers }(\mathrm{mg})\end{array}$} & \multirow{3}{*}{ of different days of nectar collection } & 18.90 \\
\hline & & 41.55 \\
\hline & & 25.90 \\
\hline & $\min . \max$. & $15.00 \quad 44.70$ \\
\hline & $\bar{\chi}$ & 29.08 \\
\hline \multirow{5}{*}{$\begin{array}{l}\text { Sugar concentration in nectar } \\
(\%)\end{array}$} & \multirow{3}{*}{ of different days of nectar collection } & 64.27 \\
\hline & & 55.92 \\
\hline & & 54.25 \\
\hline & $\min . \max$. & $53.5 \quad 65.00$ \\
\hline & $\bar{\chi}$ & 58.15 \\
\hline \multirow{4}{*}{$\begin{array}{l}\text { Weight of sugars from } 10 \\
\text { flowers }(\mathrm{mg})\end{array}$} & \multirow{3}{*}{ of different days of nectar collection } & 12.15 \\
\hline & & 23.23 \\
\hline & & 14.05 \\
\hline & $\bar{\chi}$ & 16.48 \\
\hline
\end{tabular}


together with the clearly convex subsidiary cells (Figs. 18, 20). They had different degrees of the pore opening. Closed stomata were also observed (Fig. 20).

The stomata had clearly visible outer cuticular ledges (Figs. 18-22) and much thicker inner cuticular ledges (Figs. 18, 19, 21).

The stomata were accompanied by small air cavities in which an intensively stained substance was sometimes observed, which was probably the secretion of the nectary tissues (Fig. 22). Small intercellular spaces were observed in the glandular tissue of the nectary.

\section{Nectar secretion}

Echium russicum flowers produced nectar abundantly throughout the flowering period. The weight of nectar secreted throughout the lifetime of ten flowers ranged $15-45 \mathrm{mg}$, with the average value of $29 \mathrm{mg}$. The sugar concentration in the nectar ranged between $54 \%$ and $65 \%$ with the weight of sugars from 10 flowers amounting to about $17 \mathrm{mg}$ (Tab. 1).

\section{DISCUSSION}

The nectaries of Echium russicum differ in size and shape from the nectaries of Myosotis sylvatica (Werys zk o-Chmi e lew s ka, 2003) and Symphytum officinale (Stpiczyńska, 2003) belonging to the family Boraginaceae, which are described in literature. In Echium russicum studied, the nectary gland is slightly larger than in Myosotis and much smaller than in Symphytum, what is undoubtedly associated with the size of flowers. In Symphytum flowers, the diameter of the nectary and its width along the radius was almost 2 times larger than in Echium, with a similar height of both nectaries.

Echium russicum flowers produced nectar abundantly. On the average, one flower secreted $2.9 \mathrm{mg}$ of nectar in which the weight of sugars was $1.7 \mathrm{mg}$. The sugar concentration in the nectar was $58 \%$. The obtained study results relating to the amount of nectar secreted and the weight of sugars are within the range of values given for the genus Echium by Maurizio and Grafl (1969), which were, respectively, 0.5-8.8 mg and 0.23$2.56 \mathrm{mg}$. The data mentioned in the cited paper relate to the weight of nectar secreted within 24 hours. In E. russicum investigated in Lublin, a much higher content of sugars in the nectar was found (58\%) than this value generally given in literature for Echium (17-43\%) by Maurizio and Grafl (1969) and for E. vulgare (44\%) by Klinkhamer and Veen van Wijk (1999). The data given by Stpiczyńska (2003) show that Symphytum officinale flowers produced nectar more poorly than E. russicum flowers investigated in this study. The maximum amount of nectar secreted by a Symphytum flower was $1 \mathrm{mg}$ with the sugar concentration of 29$33 \%$. The above presented comparison of the size of the nectaries and the weight of nectar secreted demonstrates that the nectary of Symphytum officinale, which is about two times larger, secreted three times less nectar than the nectary of Echium russicum.

Sucrose dominates in the nectar of Echium, similarly to many Boraginaceae representatives (Maurizio and Grafl, 1969). The authors of the cited paper report that young Echium flowers, observed before full bloom, secreted much more nectar and sugars than flowers at the end of flowering. The best time for nectar secretion and bee visitation for Echium flowers was at early afternoon hours (15.00).

\section{CONCLUSIONS}

1. The nectary gland of Echium russicum surrounds the basal part of the ovary.

2 . Nectar is secreted through numerous stomata which showed different degrees of the aperture opening of the stomata, what suggest the possibility of regulating nectar secretion. The inner cuticular ledges of the stomata were better developed than the outer ledges.

3. A high content of sugars in the nectar $(58 \%)$ proves that nectar may be collected by insects from different systematic groups.

\section{REFERENCES}

Aira M. J., Horn H., Seijo M. C., 1998. Palynological ana lysis of honeys from Portugal. Journ. Apicult. Res. 37(4): 247254.

Beales K. A., Betteridge K., Colegate S. M, Edgar J. A., 2004. Solid phase extraction and LC MS analysis of pyrrolizidine alkaloids in honeys. J. Agric. Food Chem. 52(21): 66646672.

Betteridge K., Cao Y., Colegate S. M., 2005. Impro ved method for extraction and LC MS analysis of pyrrolizidine alkaloids and their $\mathrm{N}$ oxides in honey: application to Echium vulgare honeys. J. Agric. Food Chem. 53(6): 18941902.

Boppre M., Colegate S. M., Edgar J. A., 2005. Pyrroli zidine alkaloids of Echium vulgare honey found in pure pollen. J. Agric. Food Chem. 53(3): 594600.

Culvenor C. C. J., 1985. Paterson's Curse and toxic alkaloids. Search Australia, 16(7/8): 219223

Jabłoński B., Szklanowska K., 1979. Propozycje zmiany metody badań nektarowania roślin / Proposals for changes in methods of research on nectar production of plants. Pszczel. Zesz. Nauk. 23: 105113.

Klinkhamer P. G. L., Jong T. J., Linnebank L. A., 2001. Small scale spatial patterns determine ecological relationships: an experimental exemple using nectar production rates. Ecology Letters, 4(6): 559567. 
Klinkhamer P. G. L., Veen van Wijk C. A. M., 1999. Genetic variation in floral traits of Echium vulgare. Oikos, 85(3): 515522.

Kohlmünzer S., 1993. Farmakognozja / Pharmacognosy. PZWL, Warszawa.

Leiss K. A., Klinkhamer P. G. L., 2005. Spatial distribu tion of nectar production in a natural Echium vulgare population: implications for pollinator behaviour. Basic and Applied Ecology, 6(4): 317324.

Maia M., Russo Almeida P. A., Pereira J. O., 2005. The characterization of pollen spectra in honey from Alentejo, Portugal. Silva Lusitana, 13(1): 95103.

Maurizio A., Grafl I., 1969. Das Trachtpflanzenbuch. Ehrenwirth Verlag, München.

Rejewski M. 1996. Pochodzenie łacińskich nazw roślin polskich. Przewodnik botaniczny / The origin of Latin names of Polish plants. Botanical guide. Książka i Wiedza, Warszawa.

Rutkowski L., 2006. Klucz do oznaczania roślin naczynio wych Polski niżowej / The key for identification of va scular plants in lowland Poland. Wydawnictwo Naukowe PWN, Warszawa.

Sadowska A., 2004. Rakotwórcze i trujące substancje roślinne / Carcinogenic and poisonous plant substances. SGGW, Warszawa.

Stace P., 1992. Pollen quality Paterson's curse (Echium plantagineum). Australasian Beekeeper, 93(12): 504.

Stpiczyńska M., 2003. Sekrecja nektaru w kwiatach żywokostu lekarskiego (Symphytum officinale L.) i jego skład chemiczny. / Secretion of nectar in common comfrey (Symphium officinale L.) flowers and its chemical composition. Acta Agrobot. 56(1 2): 2731.

Terrab A., Pontes A., Heredia F. J., Diez M. J., 2004. Palynological and geographical characterization of avo cado honeys in Spain. Grana, 43(2): 116121.

Valido A., Dupont Y. L., Hansen D. M., 2002. Native birds and insects, and introduced honey bees visiting Echium wildpretii (Boraginaceae) in the Canary Islands. Acta Oecologica, 23: 413419.
Weryszko Chmielewska E., 2003. Morphology and anatomy of floral nectary and corolla outgrowths of Myosotis sylvatica Hoffm. (Boraginaceae). Acta Biol. Crac. Ser. Bot. 45(1): 4348.

\section{Budowa nektarników i sekrecja nektaru w kwiatach Echium russicum J. F. Gmel.}

\section{Streszczenie}

W przeprowadzonych badaniach określono mikromorfologię nektarników w kwiatach Echium russicum J. F. Gmel. przy użyciu skaningowego mikroskopu elektronowego (SEM) oraz anatomię przy zastosowaniu mikroskopu świetlnego (LM). Zbadano obfitość nektarowania kwiatów i koncentrację cukrów w nektarze. Gruczoł nektarnikowy położony jest poniżej zalążni słupka. Składa się z 4 części odpowiadających członom zalążni. Najszersze strefy tkanki nektaronośnej znajdują się przy bruzdach, oddzielających sąsiednie części zalążni. Wydzielanie nektaru odbywało się przez anomocytyczne aparaty szparkowe, położone tylko w dolnej części nektarnika. Szparki były rozmieszczone równomiernie lub tworzyły skupienia po 2-3. Średnia liczba aparatów szparkowych na powierzchni całego nektarnika wynosiła 184. W fazie sekrecji nektaru obserwowano zarówno otwarte, jak i zamknięte oraz nie w pełni dojrzałe aparaty szparkowe.Orientacjawiększościaparatów szparkowych była równoległa do podstawy nektarnika. Powierzchnia kutykuli komórek górnej i bocznej części nektarnika była gładka, natomiast w strefie wytwarzającej szparki wykazywała różne pofałdowania, ułatwiające zatrzymywanie nektaru. Kwiaty nektarowały przez cała długość kwitnienia. Masa nektaru wydzielana przez całe życie dziesięciu kwiatów wynosiła średnio $29 \mathrm{mg}$, o koncentracji cukrów 58\% i masie cukrów osiąającej $17 \mathrm{mg}$. 
